\title{
Street-Level Judgements about Welfare Deservingness: How Jobcentre Advisors Decide about the Individual Mix of 'Support' and 'Demand' in the Delivery of Activation Policies
}

\author{
Monika Senghaas \\ Institute for Employment Research, Germany \\ E-mail: monika.senghaas@iab.de
}

This article examines how jobcentre advisors judge the individual deservingness of their clients and investigates what role these judgements play in translating activation policies into practice. The analysis draws on qualitative data gathered in a research project on back-to-work agreements that involved several German jobcentres. It is shown that advisors vary the intensity of 'demand' depending on whether benefit recipients fulfil reciprocity expectations and are deemed to have control over the unemployment situation. Whether or not they choose an enabling, supporting approach, and the extent to which they do so, depends on judgements about the client's amenability to change and the presumed outcome of labour market policy instruments. Moreover, the analysis indicates that frontline workers use experiential cues such as appearance and selfpresentation in the face-to-face encounters in order to interpret the client. The findings highlight the relevance of the normative dimension of frontline work.

Keywords Frontline work, public employment services, back-to-work agreements, Germany.

\section{Introduction}

The idea of the 'deserving' and 'undeserving' unemployed is as old as unemployment protection systems themselves. At a general level, the first unemployment insurance schemes that were established in Europe in the early twentieth century acknowledged that unemployment was an inevitable aspect of industrial life rather than a consequence of individual behaviour. Nonetheless, distinctions between different groups of unemployed persons were already inherent in these early unemployment protection systems. Insurance schemes established in states that followed the Bismarckian model of social protection (Bonoli, 1997) distinguished between unemployed persons who had 'earned' their entitlement through contributions and those who were not entitled to benefits because of their record of insufficient contribution. Activation policies can be read as a continuation of these efforts to separate the deserving from the underserving (Grundy and Laliberte Rudman, 2018). In activation policies, individual behaviour constitutes a delineation between the deserving and the undeserving unemployed. Benefit recipients who fail to demonstrate efforts to seek a job, do not attend appointments with the public employment service or do not participate in compulsory employability enhancement programmes are subject to disciplinary measures, including benefit sanctions (ibid.). 
Perceptions of deservingness are also reflected by public attitudes towards the welfare state. A growing strand of research argues that the public does not deem all groups of the population to be equally deserving of welfare support (van Oorschot et al., 2017). Criteria such as claimants' control over the situation, their need and the perceived reciprocity serve as heuristics in judgements about the deservingness of potential welfare recipients (Gielens et al., 2019; Reeskens and van der Meer, 2019). While this literature provides solid empirical insight into public judgements about the deservingness of potential welfare claimants, surprisingly little is known about how professionals in welfare organisations judge the individual deservingness of welfare claimants. Given the fact that social and labour market policies are put into practice in welfare organisations, professional judgements about welfare deservingness are a crucial aspect in the implementation of activation policies. Street-level workers in welfare organisations transform policies into practice, and their practices make a difference in shaping what policies mean for the individual (van Berkel, 2019). Moreover, in personal encounters with welfare organisation staff, citizens experience the concrete functioning of the welfare state (Dubois, 2014).

Drawing on the literature on street-level bureaucracy (Lipsky, 2010) and in particular on frontline workers' normative and moral judgements (Hasenfeld, 2010; MaynardMoody and Musheno, 2012; Zacka, 2017), this article investigates how jobcentre advisors in Germany judge the deservingness of their unemployed clients and what consequences these judgements have for the shape that activation policies take. In order to do so, the empirical analysis deciphers patterns of street-level judgements and explores how these judgements are linked to the concrete form that activation policies take. The study concerns the German basic income support scheme, a means-tested unemployment assistance scheme for individuals deemed capable of work.

The remainder of the article is structured as follows. The next section discusses the concept of deservingness and the role of frontline workers in policy implementation. The subsequent section provides a brief account of data and methods. Drawing on the example of back-to-work agreements, the analysis demonstrates how advisors individually adjust the mix of demanding and supporting elements in delivering activation policies. It is shown that street-level judgements are based on perceptions of reciprocity, the attribution of responsibility for unemployment and the assessment of a client's amenability to change. Moreover, the findings highlight that advisors' interpretations of the individual client play a crucial role in street-level judgements, and that these interpretations take into account cues such as the appearance and the self-presentation of the client. The last section summarises the results and discusses the need for further research on the normative dimension of frontline work.

\section{Theoretical background}

\section{Welfare deservingness}

The concept of welfare deservingness refers to the observation that public attitudes towards welfare support show differences between individuals and groups. Referring to de Swaan's (1988) historical study on the development of modern welfare states, Cook's (1979) survey of American views on supporting the poor, and Will's (1993) empirical study of public perceptions of the deserving poor in America, van Oorschot (2000) identified criteria and conditions applied by the public when judging the legitimacy of 
public support for certain groups of the population. He suggested five overlapping criteria that provide (potentially rivalling) cues in judgements regarding whether a person or a group deserves help: the less contro/ welfare claimants have over the situation and the less responsible they are for it, the more deserving they are in the eyes of the public. Secondly, the attitude of the person is relevant: compliance and gratefulness are positively associated with deservingness. A third criterion is reciprocity, i.e. the degree to which welfare claimants give or do something in return. This may be a 'smile of thanks, compliance and gratefulness, but also, in a modern context, actively looking for a job, or willingness to participate in a re-insertion programme' (van Oorschot, 2000: 36). Furthermore, the identity of the potential welfare claimant influences judgements regarding deservingness, with identity describing the proximity of the welfare claimant to the person assessing their deservingness. Those considered to be deserving are usually those people who belong to 'us', to a certain collective identity group, such as a local, religious, professional or national identity. The last criterion he identifies is the level of need. The greater the level of need, the more deserving people are deemed to be.

Empirical studies have demonstrated that these criteria serve as heuristics in judgements about deservingness: that is, 'decision rules that produce quick judgements based on limited information and, hence, allow for opinion formation even when substantive information is absent' (Petersen et al., 2010: 26). From research on perceptions of deservingness, we know that across countries and social categories unemployed people are usually regarded as less deserving than other groups of welfare claimants: namely, the elderly, sick or disabled (van Oorschot, 2006). Within the group of the unemployed, both individual characteristics and the behaviour of the unemployed have an influence on whether the public judges them as deserving of public welfare and to what extent (e.g. Reeskens and van der Meer, 2019).

With regard to the German basic income support scheme, which is the relevant framework for this study, factorial surveys that experimentally modified characteristics and behaviour patterns of hypothetical unemployed individuals have provided insights into the relevant decision cues. Apart from the individual need - operationalised, for example, by children living in the household or the age of the welfare claimant -, control and reciprocity have been found to be important decisions heuristics for judgements about deservingness: respondents awarded significantly lower levels of benefits to unemployed individuals who were seen to be responsible for their situation and who made little effort to find employment again than to individuals who had lost their job as a result of their employer's bankruptcy and were actively looking for a new job (Hörstermann and Andreß, 2015; Buss, 2019). Deservingness criteria were also linked to judgements about the obligations of the unemployed (Buss, 2019): whether respondents considered unemployed persons to be obliged to move to another city for work, take any available job or participate in training courses was influenced by the factor of children living in the household (need) and the name of the claimants (identity). Whether or not respondents agreed with sanctioning unemployed persons depended primarily on the behaviour of the unemployed and the reasons for unemployment (reciprocity, control).

\section{Policy-making on the ground: the importance of street-level judgements}

A growing body of empirical studies in different national and institutional contexts argues that actors and organisations delivering social and labour market policy have a decisive 
influence on the way social policy looks in practice (Brodkin and Marston, 2013; van Berkel et al., 2017). Many of these studies share Lipsky's (2010 [1980]) classical argument that practitioners in the public sector have considerable room for discretionary decisionmaking. According to Lipsky, street-level bureaucrats typically work in an environment where resources - such as time or information - are inadequate for responding to each individual case in a satisfactory manner. In his view, the routines they establish in order to cope with these working conditions and the decisions they make 'effectively become the public policies they carry out' (2010: xiii, italics in original).

Since Lipsky's seminal work was published in 1980, the conditions of work in welfare organisations have changed considerably. Performance and outcome measures and other features of New Public Management have altered the nature of frontline work. Nonetheless, discretionary decision-making remains an inevitable part of policy implementation (Evans and Harris, 2004). Frontline workers describe discretion as an inherent part of their work, even in highly rule-bound settings (Baker Collins, 2016). In such a setting, discretion may refer to the interpretation of rules and the use of the discretionary spaces provided for by the rules (e.g. 'we shall' versus 'we must', see Baker Collins, 2016: 227).

While the use of discretion has been a focal point of empirical studies investigating policy delivery at street level, less attention has been paid to the mechanisms underlying discretionary decision-making. The analysis of street-level judgements about welfare deservingness presented in this article builds on the argument that human service organisations engage in 'moral work'. The 'very action taken on behalf of clients not only represents some form of concrete service, such as counselling a family or determining eligibility for welfare, but also confers a moral judgement about their social worth, the causation of their predicament, and the desired outcome' (Hasenfeld, 2010: 97). These judgements occur in the interplay between the current normative order and the situation presented to frontline workers by the individual client (Maynard-Moody and Musheno, 2012).

When it comes to the mechanisms underlying street-level judgements, MaynardMoody and Musheno (2012) argue that frontline workers rely on normative reasoning and pragmatic improvisation - rather than on a professional use of discretion - when making these judgements. Zacka identifies moral dispositions that 'act as filters that regulate how bureaucrats make use of their discretionary power' (2017: 12). These moral dispositions contribute to how frontline workers tend to perceive and interpret situations and cases and how they tend to understand their role and responsibilities. They thus 'correspond to a propensity to handle cases according to a particular mode of appraisal' (Zacka, 2017: 79).

This strand of research provides valuable insight into how frontline workers act as moral agents. The empirical study presented in this article aims at contributing to this field of research by identifying relevant decision cues that frontline workers rely on when making moral judgements. The analysis seeks to identify whether and how frontline workers take into account characteristics and behaviour patterns of their unemployed clients when judging their deservingness, and investigates what consequences these judgements have for the shape that activation policies take.

\section{Institutional framework: the German basic income support scheme}

The study presented in this article was carried out among frontline workers in jobcentres implementing the German basic income support scheme. The basic income support scheme (Grundsicherung für Arbeitsuchende) is a means-tested unemployment assistance 
programme. This tax-funded scheme provides flat-rate benefits for unemployed individuals who are deemed capable of work and have no other benefit entitlements, and no entitlement to the compulsory unemployment insurance scheme in particular. The current benefit of EUR 432 for a single person plus expenses for rent and heating (as of January 2020) is intended to ensure a minimum level of physical and socio-cultural existence. Benefits can also be granted as an income supplement if earnings do not cover the minimum living expenses of the household (Federal Ministry of Labour and Social Affairs, 2018: 46-52). In comparison with the unemployment insurance scheme, the basic income support scheme places a particularly strong emphasis on welfare conditionality. Its overarching goal is to end or reduce benefit collection as quickly as possible. Benefit recipients must exercise all options to end welfare support, demonstrate an active job search and accept any job regardless of qualification, previous income levels and field of employment.

In 2019, around two-thirds of all unemployed persons in Germany fell under the basic income support scheme; one-third were entitled to benefits from the compulsory unemployment insurance scheme. Basic income support recipients have a lower level of education and lower professional qualifications on average than non-recipients of a similar age group (Beste et al., 2014). Employment and benefit trajectories of basic income benefit recipients are heterogeneous. While one in three new recipients remains in benefit receipt for the next three years and shows little or no employment activity, close to a quarter take up regular full-time employment and end benefit receipt soon after entry (Bruckmeier et al., 2019). There are a variety of different patterns existing between these poles, such as leaving welfare receipt with part-time work or receiving basic income support while being (marginally) employed (ibid.).

The basic income support scheme is administered by approximately 400 local jobcentres. The majority of the jobcentres are joint ventures run by the Federal Employment Agency and local municipalities. Some 100 jobcentres are managed solely by municipalities. Jobcentres grant and administer benefits, provide employment advice and apply labour market policy instruments, such as financial assistance for occupational and further training, short-term training courses or wage subsidies. Advisors in jobcentres are responsible for providing employment counselling and placement services. They also monitor clients' job search activities and compliance with other requirements. Benefit administration, on the other hand, is a back-office function conducted by specialised staff. Jobcentre advisors come from a variety of professional backgrounds. Many of them are trained in public administration or social work, although other career paths are also common (Kupka and Osiander, 2017: 94). ${ }^{1}$

\section{Data and methods}

The empirical data for this article was collected as part of a research project on back-towork agreements (Bernhard et al., 2019). Back-to-work agreements are public law contracts between the jobcentre and the benefit recipients. They define the efforts which benefit recipients have to make to end welfare collection and how jobcentres assist them. Moreover, the agreements provide information regarding financial sanctions imposed if benefit recipients fail to meet their obligations.

This article draws on qualitative data gathered in the context of a field experiment in which several German jobcentres varied the content of back-to-work agreements and the 
related sanctioning options. Between July 2017 and June 2018, participatory observations of face-to-face encounters in jobcentres were carried out and subsequently semistructured interviews were conducted with both advisors and jobseekers separately. Moreover, group discussions with advisors were conducted. Interviews, group discussions and face-to-face-encounters were audio recorded and transcribed verbatim. ${ }^{2}$

This article draws primarily on the interviews with advisors. The sample includes twenty-eight interviews. Most of them were conducted in the follow-up to face-to-face encounters observed by the researchers. I used transcripts of participatory observations of face-to-face encounters to contextualise the findings. The advisors interviewed were employees of three different jobcentres run jointly by the Federal Employment Agency and the local municipality. The interview guide focused on three main themes: the most important part was a reflection on the encounter the researchers had observed before, while the other themes were related to experiences with and evaluations of the back-towork agreement in general and the variations of the back-to-work agreement used in the field experiment.

In the starting sequence, advisors were asked to describe their impressions of the encounter. In the further course of the interview, advisors were encouraged to compare the recent encounter to situations where they had chosen a similar or different approach. It was these sequences in particular in which advisors described their interactions with clients and typical situations from their daily work - including attempts to rationalise and justify them - that provided evidence of the normative reasoning underlying street-level judgements and the context that shapes these judgements (see Maynard-Moody and Musheno, 2012: S21 for a similar observation).

I used MAXQDA qualitative data analysis software to organise and analyse the data systematically. The following sections present the results of a qualitative content analysis combining an inductive and a deductive approach (Mayring, 2000; 2019). Following the logic of a 'directed content analysis' (Hsieh and Shannon, 2005: 1281-1283), interview transcripts were analysed with regard to moral assessments and the judgement heuristics derived from deservingness theory (control, attitude, reciprocity, identity, need). In parallel, interview transcripts were examined inductively for sequences describing differentiations between individual clients and approaches chosen for specific categories of clients ('conventional content analysis', Hsieh and Shannon, 2005, 1279-1281). Categories were developed from the material, and they were refined and adapted to the material in an iterative process (Mayring, 2000). For this more exploratory element of the analysis, I considered also sequences in which interviewees described typical situations of frontline work including attempts to rationalise and justify them. When bringing together the two levels of analysis, the main decision cues for moral judgements and typical examples for these decision heuristics were identified. The relationships between categories and subcategories identified in the material provided information on how typical patterns of judgement are associated with particular forms that activation policies take.

\section{Street-level judgements in face-to-face encounters}

\section{Activation policy on the ground: the example of the back-to-work agreement}

Frontline workers in jobcentres interpret and apply legal and administrative rules to individual cases. In the delivery of social and labour market policy, they use their 
discretionary leeway to stress either the more regulatory and disciplinary elements of activation policies or those that are more enabling and empowering (Sainsbury, 2008; Brodkin, 2011). The back-to-work agreement is an illustrative example of how frontline workers shape activation policy on the ground.

As mentioned above, back-to-work agreements specify the efforts which benefit recipients have to undertake to end welfare collection and how the jobcentre assists them. Most typically, these efforts refer to job search activities that have to be documented for the jobcentre. Advisors adjust the intensity of this regulatory element of activation policy by varying the monthly minimum of job enquiries for which benefit recipients have to provide proof. When drawing up the back-to-work agreement, advisors take the labour market situation of the individual jobseeker into account. One of the interviewees described the decision-making process as follows: 'Depends on the job. Depends what profession they're applying for jobs in, and then I've got to have a look whether there are actually any jobs at all around here ... So with me it varies from two to six jobs they have to make an effort to apply for themselves' (interview 46). Besides the labour market, advisors consider the individual circumstances of the jobseeker and decide, for example, to lower the number of obligatory job search enquiries for single mothers. They may also decide to prioritise activities such as preparing application documents or participating in a language course. Some interviewees reported including related activities in the back-towork agreement, such as organising child care or stabilising mental health conditions. However, as the jobcentre cannot oblige benefit recipients to attend psychosocial counselling, for example, one interviewee described this approach as drawing up a 'pro forma back-to-work agreement' (interview 67).

Non-compliance with the requirements set down in the back-to-work agreement constitutes a reason to impose financial sanctions. Insufficient job search efforts lead to a 30 per cent cut in benefits for a period of up to three months. Before the German Federal Constitutional Court declared sanctions of more than 30 per cent to be unconstitutional in November 2019, repeated violations of obligations could result in benefits being suspended completely. In 2017 and 2018, about nine per cent of the sanctions imposed were a result of benefit recipients failing to fulfil the obligations specified in the back-to-work agreement. $^{3}$

\section{Fulfilling reciprocity expectations: the category of the 'motivated client'}

Using their discretionary leeway, advisors decide who is treated routinely, who receives harsher treatment focusing on the demanding or even disciplining elements of activation policies, and who is subject to a more supportive or enabling treatment. These decisions are based on judgements concerning the specific approach individual clients 'deserve'. The design of back-to-work agreements is an instance where the discretionary leeway of advisors and the underlying judgement categories are particularly perceptible.

Reciprocity expectations play an important role in these judgements. The idea of mutual, reciprocal relations is a long-established principle of the German welfare system. Even the first state unemployment insurance scheme that emerged in the interwar period already linked the receipt of benefits to certain conditions: only applicants who had previously contributed to the insurance scheme and who were categorised as 'available' for the labour market qualified for unemployment benefits. Activation policies have strengthened the requirements imposed on applicants for insurance benefits, resulting in a 
narrower definition of 'suitable employment' and more demanding regulations concerning occupational mobility and job search requirements (Bothfeld and Rosenthal, 2018). In the basic income support scheme, reciprocity expectations are particularly pronounced. Means-tested benefits are conditional on the applicants' 'willingness to work'. These reciprocity expectations and related behavioural rules are taught in face-to-face encounters. Interview sequences addressing typical situations in frontline work suggest that frontline workers regularly refer to norms such as cooperation with the jobcentre ('Everyone who comes into the jobcentre basically commits to actively cooperating for the time being. And I assume that as well, and that's what I say to the customers too, interview 19) and self-responsibility ('Well, I try to explain that no-one's going to knock on your door and ask, "Would you like to work for me?" but that you're going to have to take action yourself', interview 45) in face-to-face encounters.

It is a widely shared practice to illustrate the consequences of non-compliance, particularly in the first meeting with clients. However, advisors vary the intensity of sanctioning threats based on their judgement of the individual jobseeker. 'Motivation' is a crucial category linked with reciprocity expectations. The following interview sequence exemplifies how advisors vary their conduct depending on judgements about a client's motivation: 'And it's the oldest story in the world: if someone gives you money, they want something for it. Just to break it down. And that's what I say to the customers as well if I notice that they somehow don't exactly have the drive' (interview 33). Many interviewees deemed back-to-work agreements and the related possibilities of sanctioning to be of little importance when advising clients they typified as 'motivated'. In contrast, when confronted with a client judged to be 'lacking motivation', frontline workers point out the consequences of 'insufficient cooperation' with the labour administration more precisely and tend to increase the frequency of personal contact to monitor clients.

Showing initiative and being proactive in developing strategies for (re-)employment are powerful cues when it comes to judgements about a client's motivation. Compliance with institutional rules, such as handing in documents or bringing them along to the meeting, also signals motivation and thus the fulfilling of reciprocity expectations. Asked how they would recognise a motivated client, advisors also referred to more general cues such as a client's engagement in the conversation ('is the conversation very one-sided or is it really more of a dialogue', interview 19).

\section{Adjusting individual obligations according to the level of control}

Judgements about a client's motivation and the related choice of a more or less demanding approach reflect the normative principles underlying activation policies, particularly individual responsibilities and welfare conditionality. Although motivation is a crucial category in street-level judgements, situations that arise on the front line cannot be reduced to the dichotomy of motivated versus unmotivated clients. In many instances, the principle of individual responsibility and employability enhancement reaches its limits. The following quote from an interview with an advisor counselling jobseekers classified as 'remote from the labour market' illustrates these tensions between political principles and situations that arise on the front line. Referring to the specificities in his team, the interviewee explains: 
That means that in very many cases ... there are also a lot of people who just aren't motivated. That means it often happens that you have to wag your finger at them. But then again I have to say that some of [the clientele] are people who are really ill. Who show us physically what's not possible. We have people on substitution treatment with methadone, drug addicts, we have alcoholics. People who really are weak physically (interview 33).

The advisor quoted here draws a line between jobseekers lacking motivation and those who are sick or struggling with an addiction and explains that, in the latter case, a regulatory approach focusing on self-responsibility and threats of sanctions does not provide a functional alternative. The same pattern of argument was found with reference to jobseekers facing specific difficulties on the labour market and restrictions in their job search due to health impairments, but also due to personal circumstances or long episodes of unemployment. In these cases, advisors describe the spectrum of demand as being limited ('what isn't possible'). After a meeting with a client in his fifties who has been unemployed for more than fifteen years, including an episode of homelessness, one advisor explains, 'I'm aware now ... that I can't start demanding that he should apply for jobs proactively or whatever. That's clear' (interview 42). Another advisor reported exempting one jobseeker who had quit her previous job because of health-related problems from job search obligations 'because in that area or in our work with customers with health limitations like she [the customer] has, it makes no sense at all in our experience' (interview 49).

These examples demonstrate how frontline workers adjust individual obligations according to their judgement of the individual circumstances and capacities of the clients. While a client lacking motivation is deemed to have the potential to stop receiving welfare by actively searching for work, in other cases unemployment is seen as being caused by circumstances beyond the immediate control of the jobseeker. Based on their judgement of the extent to which a person is 'blamed' for being unemployed, advisors may thus decide to exempt benefit recipients from obligations.

\section{Perceived amenability to change and allocation of resources}

The deductive analysis of the material revealed that the extent to which unemployed clients fulfil reciprocity expectations and are deemed to have control over the situation of unemployment are important cues in street-level deservingness judgements. No consistent evidence across individual cases was found, on the other hand, for whether or how advisors base their judgements on the criteria of need, attitude and identity. However, other categories that frontline workers take into account when judging what approach an individual client deserves emerged from the inductive analysis of the interview transcripts.

As the last quote in the previous section already suggests, the 'outcome' of a specific intervention does play a role in street-level judgements. The advisor explains that 'it makes no sense at all in our experience' to define job search obligations for clients with severe health-related problems. Here, the perceived outcome shapes the definition of individual obligations. Furthermore, the perceived amenability to change makes a difference when it comes to the allocation of resources to an individual case (Hasenfeld, 2010: 99). Frontline workers act as gatekeepers to public services, and given the limitation of resources such as time or funds, they commonly develop strategies to ration services (Lipsky, 2010: 105-116). 
While advisors increase the frequency of direct contact when they judge jobseekers to be lacking in motivation, they often make less frequent appointments with clients typified as being remote from the labour market. The rationing of services also concerns the assignment to short-term training courses of an enabling nature and further vocational training. ${ }^{4}$ A typical example of this dimension of street-level judgements is an interviewee who explains with regard to a client from a migration background that the outcome of a training course would not be promising due to the language barrier:

This Romanian cleaner - where is she supposed to apply to six times a month? She hasn't even got any application documents. Even though we've got a great agency and everything that does that with the customers, to do that you have to speak at least a bit of German. And I can't do that with her (interview 22).

The frontline worker justifies the decision not to allocate resources to that individual case with the perceived limited outcome of a training course. A similar mechanism of judgement is described in an interview with an advisor offering intensified counselling for clients who are long-term unemployed or who face this risk. The advisor explains that choosing the 'right' clients for this particular type of intervention is essential and refers to the presumed outcome as the important dimension: cues that have proved useful, according to this advisor, are a client's 'willingness to change' in combination with a 'realistic chance' of finding employment on the regular labour market (interview 67).

\section{Using 'soft evidence' to interpret the client in face-to-face encounters}

The way the administration functions requires the advisors to interpret rules and apply them to individual cases. The analysis presented in the previous sections shows that advisors not only interpret rules, but also interpret 'cases'. Face-to-face encounters are crucial times for these interpretations to develop, and they rely in part on cues which are only accessible in personal encounters. Whereas job search efforts can be assessed on the basis of documents provided by the client, for example, frontline workers use more subtle cues from the personal meeting to draw an overall picture of the individual client. After meeting a thirty-year-old unemployed man who approaches the public employment service for the first time and does not report any work experience or provide any information as to what he has done since he left school, one advisor reflects the 'deciphering' of the client in the research interview as follows: 'I haven't really been able to figure him out yet. Because the way he presents himself and how he sits there in front of you, well, actually you wonder why he's sitting here at all. He could be doing something completely different' (interview 22).

This interview sequence provides an insight into how advisors reconstruct a client's identity using 'soft evidence' (Zacka, 2017: 57-58) such as appearance, manner of speech, body language or the expression or concealment of emotions. Not having made a final assessment of the client, the advisor quoted above suggests a short-term training course which he describes in the research interview as 'kind of like a test balloon. That can still be managed from a cost point of view' (interview 22). Another advisor referred to a similar mechanism when she reported assigning benefit recipients whom she suspected of having undeclared income to short-term training courses in order to test their willingness to work. The advisor refers to the appearance of the clients to justify her interpretation: 'If you see 
that he's actually much too well-dressed for someone on unemployment benefit. ... And there are really signs, whether it's their watch or a new hairstyle every day' (interview 67).

To be sure, all of the categories of judgements identified in the analysis so far are subject to individual prioritisation and assessment by frontline workers. If clients do not prove that they have made efforts to search for a job as defined in the back-to-work agreement, frontline workers may read this as a sign of low reciprocity, and emphasise the disciplinary elements of activation policies. When focusing on difficult personal circumstances that the client is temporarily facing, however, they may also come to the decision that the client has no control over the unemployment situation and exempt them from obligations for the meantime. Experiential cues such as appearance and the way someone presents themselves in the encounter, however, appear to be particularly subjective and prone to the danger of inconsistent treatment (Zacka, 2017: 58). Nonetheless, factors such as these which cannot be precisely measured and their assessment on the basis of training and experience are a necessary dimension of street-level discretion as there is no 'programmatic recipe that performs better' (ibid.). In order to assess a client's situation on the labour market and define suitable instruments and interventions, frontline workers not only need information about a client's formal qualifications and work experience, but also about their individual situation, motivation and interests (Senghaas et al., 2019: 620). Experiential cues may complement or replace information provided by the client.

In the interviews, frontline workers justify their interpretations on the basis of 'soft evidence' by references to 'typical' patterns of appearance and behaviour. The frontline worker trying to decipher the young man who did not give any information about his past, for example, concludes in the interview: 'well, he doesn't actually fit in here, not really I think' (interview 22). Street-level judgements therefore do not only reflect moral assumptions institutionalised by the current legislation, such as the norms of reciprocity and cooperation with the jobcentre. Advisors also judge the individual deservingness of a client against the background of generalised expectations about the 'typical' client.

\section{Conclusion}

This article examined how frontline workers judge the individual deservingness of their unemployed clients and how these street-level judgements affect the shape of activation policies. Drawing on qualitative interviews with jobcentre advisors conducted in a research project on back-to-work agreements, it was shown that advisors define the practical meaning of activation policies by deciding who is treated routinely, who receives harsher treatment focusing on the disciplinary elements of activation policies, and who is subject to more supportive or enabling treatment.

The analysis revealed that some criteria which the public applies when judging the welfare deservingness of individuals or groups (van Oorschot, 2000; van Oorschot et al., 2017) also provide cues for street-level judgements about what an individual client deserves. Jobcentre advisors vary the intensity of 'demand' depending on whether benefit recipients fulfil reciprocity expectations - specifically looking for a job actively and cooperating with the jobcentre - and are deemed to have control over the unemployment situation. Clients typified as unmotivated therefore typically receive harsher treatment than clients considered to be motivated, while clients who are considered to have little control over their situation are often exempt from job search obligations that are usually set down in the back-to-work agreement. 
No consistent empirical evidence was found, however, on whether or how advisors take into account the criteria of need, attitude and identity, which serve as decision heuristics in public deservingness judgements. In the inductive analysis of the material, the category of the perceived outcome emerged as an important factor instead. Whether advisors choose an enabling approach, treat a client routinely or decide to ration services is linked to judgements about the client's amenability to change and the presumed outcome of the allocation of resources such as counselling time or training programmes. Furthermore, advisors use experiential evidence from the face-to-face encounters, such as appearance and the way clients present themselves, to interpret the client's deservingness.

In line with other studies on the frontline delivery of activation policies (e.g. Sainsbury, 2008; Tabin and Perriard, 2016; Senghaas et al., 2019), the findings presented in this article stress the multifaceted nature of the frontline delivery of activation policies, that encompasses enabling as well as disciplinary features. It was shown that frontline workers do not simply implement social policy programmes by applying legal regulations to individual cases. Inherent to their work are judgements about 'worthy' and 'unworthy' clients (Hasenfeld, 2010), and using discretion necessarily involves judgements about questions of value (Zacka, 2017). The findings contribute to existing research on the moral dimension of street-level work by providing insights into the mechanisms that underlie these judgements. It was shown that decision heuristics derived from deservingness theory provide a useful starting point to grasp the nature of street-level judgements and the underlying categorisation processes.

The study is exploratory in nature and does not allow generalised conclusions to be drawn about the relationship between public and professional judgements. In particular, it is not possible to determine whether frontline workers' attitudes towards welfare recipients are more positive in general than those among the public, as a survey conducted in Finland has shown (Kallio and Kouvo, 2015). What has become clear, though, is that both professional and public judgements reflect normative principles institutionalised in current legislation. In factorial surveys, the individual behaviour of unemployed people constituted a delineating line between the more and less deserving unemployed: respondents awarded significantly more benefits to unemployed individuals who showed efforts to end their situation of unemployment (Hörstermann and Andreß, 2015; Buss, 2019). In a similar way, street-level judgements take the compliance with legal requirements and norms such as cooperation with the jobcentre into account and vary the intensity of 'demand' according to the fulfilling of reciprocity expectations.

What is remarkable is the nuanced assessment of control in street-level judgements. Possible limitations to the clients' ability to change their situation due to health impairments or difficult personal circumstances were a prominent theme in the interviews. This may reflect the fact that due to a broad definition of the capability to work, the German basic income support scheme includes persons on the margins with regard to the capability to work who might in other institutional settings receive other types of benefit such as invalidity or disability benefit (Konle-Seidl et al., 2014). Anyone who is able to work at least three hours a day under the usual conditions of the labour market falls under the basic income support scheme and, as a consequence, is expected to exercise all options to end welfare support and demonstrate an active job search. At this point, tensions between political principles and situations that arise on the front line become particularly perceptible. Moreover, professional judgements are shaped by the various goals and demands that frontline workers are juggling in their daily work (Zacka, 2017). 
That frontline workers take into account the perceived outcome in the decision as to whether a client deserves to be allocated counselling time or funds for training courses can be read as a response to the demand to use public resources efficiently.

Ultimately, a particularity of street-level judgements is that they are informed by the personal encounter and use cues which are peculiar to the face-to-face nature of streetlevel work. Frontline workers not only interpret rules and regulations when applying them to individual cases, they also interpret individual clients. Factors such as a client's appearance, their engagement in the conversation and their self-presentation serve as cues in these interpretations and complement information provided by the clients. On the basis of the data analysed in this article it is not possible to assess whether and to what extent these interpretations are shaped by the distinctive identities that frontline workers bring to the encounter (Dubois, 2010). Future research on frontline work should shed more light on the social identities that advisors and clients bring to the encounter and the interplay between these identities.

\section{Notes}

1 Unfortunately, there are no reliable figures available on the educational and occupational background of jobcentre advisors (Kupka and Osiander, 2017: 94).

2 Advisors and jobseekers gave their verbal consent to the recording of the interview/group discussion/face-to-face encounter and signed a declaration of consent after the interview/group discussions were completed. All except one advisor agreed to the audiotaping.

3 https://statistik.arbeitsagentur.de/Navigation/Statistik/Statistik-nach-Themen/Grundsicherungfuer-Arbeitsuchende-SGBII/Sanktionen-Widersprueche-Klagen/Sanktionen-Widersprueche-KlagenNav.html.

More than three-quarters of all sanctions arise due to jobseekers missing appointments with the jobcentre; another ten per cent concern the refusal to commence or continue an employment, apprenticeship or labour market policy programme.

4 Some short-term programmes such as application training are primarily used to test willingness to work, while others, such as skill training (computer or language training), are of a more enabling nature. Further vocational training courses are particularly enabling and have been found to have an especially strong effect on future job quality (Dengler, 2019).

\section{References}

Baker Collins, S. (2016) 'The space in the rules: bureaucratic discretion in the administration of Ontario Works', Social Policy and Society, 15,2, 221-35.

Bernhard, S., Senghaas, M., Freier, C., Ramos Lobato, P. and Stephan, G. (2019) 'Vertragsbeziehungen zwischen Jobcentern und Arbeitslosen. Eingliederungsvereinbarungen aus Sicht von Arbeitsvermittlerinnen und Arbeitsvermittlern', IAB-Forschungsbericht, 2/2019.

Beste, J., Bethmann, A. and Gundert, S. (2014) 'Sozialstruktur und Lebensumstände. Materielle und soziale Lage der ALG-II-Empfänger', IAB-Kurzbericht, 24/2014.

Bonoli, G. (1997) 'Classifying welfare states: a two-dimensional approach', Journal of Social Policy, 26, 3, $351-72$.

Bothfeld, S. and Rosenthal, P. (2018) 'The end of social security as we know it: the erosion of status protection in German labour market policy', Journal of Social Policy, 47, 2, 275-94.

Brodkin, E. (2011) 'Policy work: street-level organizations under New Managerialism', Journal of Public Administration Research and Theory, 21, Suppl 2, 253-77.

Brodkin, E. and Marston, G. (eds.) (2013) Work and the Welfare State: Street-Level Organizations and Workfare Politics, Washington: Georgetown University Press. 
Bruckmeier, K., Lietzmann, T. and Saile, A. (2019) 'Welfare dynamics and employment: heterogeneous paths through means-tested basic income in Germany, Journal of Social Policy, 49, 2, 271-97.

Buss, C. (2019) 'Public opinion towards targeted labour market policies: a vignette study on the perceived deservingness of the unemployed', Journal of European Social Policy, 29, 2, 228-40.

Cook, F. (1979) Who Should Be Helped? Public Support for Social Services, Thousand Oaks: Sage.

Dengler, K. (2019) 'Effectiveness of active labour market programmes on the job quality of welfare recipients in Germany', Journal of Social Policy, 48, 4, 807-38.

Dubois, V. (2010) The Bureaucrat and the Poor. Encounters in French Welfare Offices, London: Routledge.

Dubois, V. (2014) 'The state, legal rigor, and the poor: the daily practice of welfare control', Social Analysis, $58,3,38-55$.

Evans, T. and Harris, J. (2004) 'Street-level bureaucracy, social work and the (exaggerated) death of discretion', British Journal of Social Work, 34, 6, 871-95.

Federal Ministry of Labour and Social Affairs (2018) Social Security at a Glance 2018, Bonn: Federal Ministry of Labour and Social Affairs, https://www.bmas.de/SharedDocs/Downloads/DE/PDFPublikationen/a998-social-security-at-a-glance-total-summary.pdf [accessed 29.09.2019].

Gielens, E., Roosma, F. and Achterberg, P. (2019) 'Deservingness in the eye of the beholder: a vignette study on the moderating role of cultural profiles in supporting activation policies', International Journal of Social Welfare, 28, 4, 442-53.

Grundy, J. and Laliberte Rudman, D. (2018) 'Deciphering deservingness: Canadian employment insurance reforms in historical perspective', Social Policy and Administration, 52, 3, 809-25.

Hasenfeld, Y. (2010) Organizational forms as moral practice: the case of welfare departments, In Y. Hasenfeld (ed.), Human Services as Complex Organizations, Thousand Oaks: Sage, 97-114.

Hörstermann, K. and Andreß, H. (2015) "'Wer nicht arbeiten will, soll auch nicht essen!" Eine Vignettenanalyse zur Bestimmung eines Einkommensmindestbedarfs', Zeitschrift für Sozialreform, 61, 2, 171-98.

Hsieh, H. and Shannon, S. (2005) 'Three approaches to qualitative content analysis', Qualitative Health Research, 15, 9, 1277-88.

Kallio, J. and Kouvo, A. (2015) "Street-level bureaucrats" and the general public's deservingness perceptions of social assistance recipients in Finland', Social Policy and Administration, 49, 3, 316-34.

Konle-Seidl, R., Rhein, T. and Trübswetter, P. (2014) 'Arbeitsmärkte im europäischen Vergleich. Erwerbslose und Inaktive in verschiedenen Sozialsystemen', IAB-Kurzbericht, 8/2014.

Kupka, P. and Osiander, C. (2017) Activation "made in Germany". Welfare-to-work services under "Social Code II", in R. van Berkel, D. Caswell, P. Kupka and F. Larsen (eds.), Frontline Delivery of Welfare-toWork Policies in Europe. Activating the Unemployed, London: Routledge, 88-106.

Lipsky, M. (2010) [1980] Street-Level Bureaucracy. Dilemmas of the Individual in Public Services, New York: Russell Sage Foundation.

Maynard-Moody, S. and Musheno, M. (2012) 'Social equities and inequities in practice: street-level workers as agents and pragmatists', Public Administration Review, 72, S1, S16-S23.

Mayring, P. (2000) 'Qualitative content analysis', Forum: Qualitative Social Research, 1,2, Art. 20.

Mayring, P. (2019) 'Qualitative content analysis: demarcation, varieties, developments', Forum: Qualitative Social Research, 20, 3, Art. 16.

Petersen, M., Slothuus, R., Stubager, R. and Togeby, L. (2010) 'Deservingness versus values in public opinion on welfare: the automaticity of the deservingness heuristics', European Journal of Political Research, 50, 1, 24-52.

Reeskens, T. and van der Meer, T. (2019) 'The inevitable deservingness gap: a study into the insurmountable immigrant penalty in perceived welfare deservingness', Journal of European Social Policy, 29, 2, 166-81.

Sainsbury, R. (2008) 'Administrative justice, discretion and the 'welfare to work' project', Journal of Social Welfare and Family Law, 30, 4, 323-38. 
Senghaas, M., Freier, C. and Kupka, P. (2019) 'Practices of activation in frontline interactions: coercion, persuation, and the role of trust in activation policies in Germany', Social Policy and Administration, $53,5,613-26$.

de Swaan, A. (1988) In Care of the State. Health Care, Education, and Welfare in Europea and the USA in the Modern Era, Cambridge: Polity Press.

Tabin, J. and Perriard, A. (2016) 'Active social policies revisited by social workers', European Journal of Social Work, 19, 3/4, 441-454.

van Berkel, R. (2019) 'Making welfare conditional: a street-level perspective', Social Policy and Administration, 54, 2, 191-204.

van Berkel, R., Caswell, D., Kupka, P. and Larsen, F. (eds.) (2017) Frontline Delivery of Welfare-to-Work Policies in Europe. Activating the Unemployed, London: Routledge.

van Oorschot, W. (2000) 'Who should get what, and why? On deservingness criteria and the conditionality of solidarity among the public', Policy and Politics, 28, 1, 33-48.

van Oorschot, W. (2006) 'Making the difference in social Europe: deservingness perceptions among citizens of European welfare states', Journal of European Social Policy, 16, 1, 23-42.

van Oorschot, W., Roosma, F., Meuleman, B. and Reeskens, T. (eds.) (2017) The Social Legitimacy of Targeted Welfare: Attitudes to Welfare Deservingness, Cheltenham, UK: Edward Elgar Publishing.

Will, J. (1993) 'The dimension of poverty. Public perceptions of the deserving poor', Social Science Research, 22, 3, 312-32.

Zacka, B. (2017) When the State Meets the Street. Public Service and Moral Agency, Cambridge, Massachusetts: The Belknap Press of Harvard. 